\title{
EXPLORING YOUNG LEARNERS TEACHERS COMPETENCY AND CHALLENGES IN TEACHING ENGLISH
}

\author{
Natalia Anggrarini \\ S1 - English Education Deparment \\ Wiralodra University - Indramayu \\ natalia.anggrarini@unwir.ac.id
}

\begin{abstract}
Competency is a set of knowledge, skill and experience necessary for the future, which manifest in their activity (White, 1959). Teaching competency reflects how teacher's ability in teaching and learning activity. Regarding to English teaching and learning to foreign learners, young learners are also exposed to have this language mastery. But Indonesian Government (see 2013 Curriculum of Elementary School) limits the subjects in Elementary School into six subjects and English is excluded. For some elementary schools, English is not give, but some others English is put as Local Content. The decision of local content here is based on the need of society, and it is happened in some elementary school in Indramayu. Thus, an English teacher for young learners in some elementary schools should reflect their competency in teaching English. She/he should be occupied with knowledge, skill and experience that needed to teach English to young learners so the purpose can meet the need. The aim of this research is to find out teaching competence of English teacher in teaching English to young learners. By conducting qualitative descriptive, this research uncovered the competency of teacher in planning the lesson, media and the implementation so it can be a consideration to put back English subject as one of main subjects in Elementary School. From the finding, it can be seen that some English teachers had made their efforts on performing good ability in teaching English such as in lesson planning, teaching media, teaching and learning activity and teaching assessment. While the challenges in teaching English to young learners were from students' behavior. The students' unawareness, unwillingness and laziness to study were the challenges of teaching English for young learners.
\end{abstract}

Key words: teaching competency, teaching English to young learners, teaching creativity

\section{INTRODUCTION}

The education is dynamic world that has always changes to find the suitable system. The change of education system always bring pro and contra statement on society. It also happens in Indonesian education system which includes the happening change of Curriculum 2013 which exclude English subject as main subject to become local content and even extracurricular in the elementary school. The changing of curriculum influences the presence of lesson plan in teaching English for young learner. Thus, it becomes challenges for the teachers to create lesson plan by considering the student need. The circumstances in teaching English for Young Learners are different with teaching English for adults which is considered by their 
physical and psychological needs. Young learners are considered to have low consciousness in learning which gives impact that they can easily lost their interest and motivation then they will be more active to do another activities except learning itself. This statement is stated by Pinter (2006) who also tells that Young Learners enjoy fantasy, imagination and movement which mean they need appropriate strategies to guide their focus in learning English based on their likes. The ability to design lesson plan is essential for the teachers so all aspects above can be fulfilled in English learning activity. This current study considers the existence of lesson plan has the role important to guide teachers in building the arranged activities which make students more engaged in learning process because they will be focus to reach the objective of lesson. Moreover lesson plan can develop the teachers' competence in making the better lesson. It has the same direction as the Brown (2001) defines lesson plan as the step arrangement in teaching lesson which involves the pre, whilst and post activities thus make a teacher have preparation to do and evaluate the lesson.

Nesari and Haidari (2014) in their study stated the advantage of lesson plan is to make the teachers have their time, effort and resources well-organized. This study explains that the teachers will use their time effectively because the learning activity has been arranged in lesson plan. In other words, the teacher will not waste their time to think about what they should do in the teaching and learning activity. The lesson plan also helps the teachers to prevent uninterested class by serving variation of activities, methods and materials. So the objective of learning will be achieved properly through the readiness of the teachers.

The other relevant study to Teaching English for Young Learner is conducted by Ismail (2004) who stated that the involvement of students in learning activity will create enjoyable situation. In this case the teachers' competence will be needed to make the learning activity more interesting and it is applied through games and song. The interesting atmosphere of learning activity is really essential in Teaching English for Young Learner and it has been mentioned by Ismail (2004) that teacher and students must collaborate to build enjoyable situation. However this collaboration must be guide or started from the teachers' creativity. This previous study does not reveal the sequence process of the implementation for teacher's creativity. Then it brings the lack information about how the teacher's creativity influences the students. So the researcher conducts the current study to prove the influence of teacher's creativity.

In this current study, the teachers' competency in planning, implementing and evaluating their teaching in the classroom is investigated. The factual circumstances related to the practice implementation of lesson plan at elementary school are uncovered. Considering the necessary of the finding and discussion thus this study is focused on the lesson plan, the implementation and the assessment related to English learning process in Elementary School. Hopefully this research will be valuable for the consideration for the policy of including English Subject as main subject in Elementary School.

\section{LITERATURE REVIEW}

\section{Characteristics of Young Learners}

The difference between young and adult learners is not actually limited to the age, but it refers to the unique nature that belongs to them. Furthermore the young 
learners who are at same age range will have different competence as well because of their nature. Related to the education world, this phenomenon should be understood by the teacher and parents to get the best out of learning process. In this case, Pinter (2006) helps teacher to map young learners' characteristic by saying that young learners as children have their own fantasy and imagination which construct the satisfaction of movement for them. These characteristic will give the effect to young learners' behavior which are usually more concerned about themselves than others.

Based on the explanation above, Cameron (2001) adds that the teachers take the crucial role to make preparation because there should be classroom activities that is appropriate for children's point of view who have their own limited way to build the understanding of what teacher says. Then the preparation of classroom activities refers to the necessary of lesson plan and it concludes that teachers should have competence to create lesson plan in the purpose to guide teacher in reaching the objective of learning.

\section{Lesson Plan}

The objective of language learning is building the ability among students to communicate and it is applied through the learning activities. In this case the output of learning activity will be affected by the preparation of teacher in facing the various occurrence and possibility that will happen at class. Considering the needs of maximizing the output of learning Angrarini (2016) states that teachers should have teaching planning which guides them to conduct the activities related to students' need and classroom condition and it is called lesson plan. This condition is also supported by Brown (2001) who defines the lesson plan as the step arrangement in teaching lesson which involves the pre, whilst and post activities, thus make a teacher have preparation to do, evaluate, and make better lesson. However there is possibility for real condition of learning activity which shows the different situation with the planning that teacher has prepared. This condition has the same definition of lesson plan which is stated by Woodward (2001) who says there is no limited form of lesson plan that only focuses to the written form but it can be the others teacher activity such as reading resources and visualizing to prepare the next lesson.

The definition of lesson plan exactly will reveal the necessary of using lesson plan for teacher as conveyed by Harmer (2001) there are two significant reasons behind the necessary of using lesson plan. First it becomes the guide for teacher, even there will be changes on the process or adaptation related to the learning activity, the lesson plan will keep the teacher on the track. Second the lesson plan can develop the relationship between teacher and student, because teacher will consider the characteristic of students and what they need in the learning process so that teacher can put and get the trust of students.

As said before that there will be possibility for unexpected occurrences happen even teacher has planned the lesson plan so well. Anggrarini (2016) states the unexpected occurrences that frequently happen in learning activity. First, an external disturbance, problem can come from outside the class and it usually attracts students and surprises teacher because the concentration of them will be broken. For instance, fire engines or ambulance are passing, in this case students must have their interest to that source and teachers must solve it by catching the chance to use 
that phenomenon in learning activity and take students back in the lesson plan. Second, an internal disturbance, the next unexpected occurrence can be found also inside the classroom and usually it comes from the students. Teacher must know first the reasons why the students make a noise for example or they want, actually then teacher are easier to solve this. The third occurrence comes to the out of control class. This situation requires teacher to do emergency activities or the other activities that has relation the material to change the previous one. The occurrence that is served actually asks the good forwardness of teacher in solving the class problem especially to lesson plan because the continuity of learning activity will depend on teachers' preparation. The fourth occurrence that should be faced by teacher readily is when an activity does not work. It has the similarity with the previous one which requires teacher to have reserve activities that can change the activity that does not support at that time. Furthermore if there is something wrong with the learning media, teacher does not need to take time by repairing it because actually being wasting time but it is necessary for teacher to tell students the real condition that is happening

\section{Teaching media}

Media is one of essential part in teaching and learning process, it is also for teaching English to young learners. Young learners need something to maintain their concentration so the teachers have to provide good and interesting materials. Teaching media used in teaching English to young learners should be effective and interesting, as Suyanto cited in Suharsih and Hamidiyah (2012) said that effective and interesting media help the students to understand material easily. The media that can be used are flashcards, diagram, chart, poster, video/film, animation, audio, power point, smart board, puppet, realia.

\section{Textbook}

The implementation of lesson plan will be helped by the using of textbook and it is supported through the statement of Harmer (2001) who says that the teachers have choices whether using textbook or not because it should be considered through the language, content and sequencing of the textbook to the students' need. In other side, teachers should do some actions such as omit, adapt, replace, and add the lesson as the response when the content of textbook is not appropriate for students.

\section{Teacher's Knowledge and Professional Skill}

According to Anggrarini (2016) the real teacher must be able to overcome the problem which needs the skill in teaching. The teachers also need the strategy to ensure the goal of teaching activities. The teachers must master what are the suitable ways including the communicative and teaching strategies. Here are the criteria of the explanation above.

\section{Mastered the subject}

The mastery of subject is necessary to teach English for young learner and then it involve the material, linking ideas, ways of thinking and arguing.

\section{Teaching Strategy}

The teachers have to find the exactly way to give the material for the students so they can comprehend it thoroughly and then it is not only limited to the traditional method such as too emphasize the student has to sit quietly, be a 
passive listener and asked students to memorize the information. The teacher must think creatively to develop learning activity.

\section{Goal Setting and Planning Skills Instructional}

The teachers should have the ability to choose the appropriate learning activity for students which is implemented by determining the learning objectives and devise a plan to achieve that goal.

\section{Classroom Management Skill}

One of skills that teacher should be mastered is creating the conducive class which has good atmosphere to create conducive and active to tasks and learning.

\section{Motivational Skill}

The interest of students should take the teachers' attention because it can give them chance to think creatively and deeply. Considering this condition, the teachers should support students by giving them motivation.

\section{RESEARCH METHODOLOGY}

This research belongs to descriptive qualitative research. It is same as the definition which is stated by Newman (2012) who defines the qualitative research as the kind of study which is designed to investigate the social process by considering the context related to the case. Therefore qualitative research was done to investigate teaching competency and challenges of English teacher in teaching English to young learners then the data was described descriptively. Three English teachers in three elementary schools in Indramayu participated in this research. There were two kinds of instruments in this research; a questionnaire and a set of interview. The questionnaire served questions relate the teaching planning and teaching implementation. While the Interview was conducted to confirm the questionnaire.

\section{FINDING AND INTERPRETATION Material Choices}

The changes of Indonesian education system which involves the 2013 curriculum really affect to learning activities. It is caused the elimination of English subject as the main course at elementary school. Furthermore the responsibility of teacher will be more difficult to make lesson plan because there is no guide from the government anymore. In this case the teachers whose school conducts English as the local content or even extracurricular have to create lesson plan by themselves. Considering this situation, the teachers should be creative to make lesson plan related to students need.

Teacher in this school still uses the syllabus which comes from the old curriculum, KTSP as the guidance to make lesson plan. However the main consideration is students' need. In this case, the students' needs are different one to another. There will be possibility actually of students to have substantial different competence among them who have the same age range. This common phenomenon is supported by Pinter (2006) who states that the young learners who are at same age range will have different competence as well because of their nature. In this study, the researcher finds the data from questionnaire that the teacher is able to overcome students' different needs by considering their daily life to choose the material. 
Table 1.1

Questionnaire about Material and Topic

\begin{tabular}{|l|l|c|c|}
\hline No & Items & Yes & No \\
\hline 1. & $\begin{array}{l}\text { Do English materials you give to the students } \\
\text { relate to their daily life? }\end{array}$ & 3 & - \\
\hline 2. & $\begin{array}{l}\text { Are the topics in your teaching planning taken } \\
\text { from their interest? }\end{array}$ & 3 & - \\
\hline
\end{tabular}

Based on the positive answer to the questionnaires above, all of the teachers answered yes for relating the material with daily life and choosing the topics that the students were interested. It was then confirmed for the interview from T3.

Usually we will put the priority for the material that relate to students' daily life such as fruits, vegetables, and animals so it will make them easier to learn. Because when students do not have any experience to the material, they will be harder to understand it.

This data guides the researcher to define the experience of students to the material is really necessary because it serves the background knowledge for them to recognize the material and comprehend it totally. Then it is the obligation for the teachers to be creative in identifying the students' needs relate to their daily life and elaborate to the preparation of learning activity, thus the lesson plan can be created properly.

\section{Integrating Textbook}

The sources of teaching English can be gotten through the textbook and it will guide the teachers to explore more about the materials, but the use of text book does not limit the teacher's creativity, because the students' needs will be the priority of teaching and learning activities. It has been said before that teachers consider the students need in creating lesson plan and this condition also happens to the use of text book. The teacher in this research uses the textbook, it is found from the questionnaire

Table 1.2

Questionnaire about textbook

\begin{tabular}{|l|l|c|c|}
\hline No & Item & Yes & No \\
\hline 3. & $\begin{array}{l}\text { Does your teaching planning take the material } \\
\text { from textbook? }\end{array}$ & 3 & - \\
\hline
\end{tabular}

All of the teachers also considered textbook material to create lesson plan. T2 gave further information related to this case by saying this statement.

Literally our school serves Erlangga textbook and LKS, so we can use them as the source, but they are not used at the same time, because we will orient to the students' need so there will be material adaptation.

However she adapted the materials by positioning it as the priority. It is in line to Harmer (2001) who says that the teachers have choices whether using textbook or not because it should be considered through the language, content and sequencing of the textbook to the students' need. In other side, teachers should do some actions such as omit, adapt, replace, and add the lesson as the response when the content of textbook is not appropriate for students. Thus, it can be said that the existence of textbook gives the improvement for teachers to create lesson plan as 
long as they put the students as consideration.

\section{The Challenges of Teaching English for Young Learner}

Teaching English for young learner is the quite challenging because the responsibility of teacher is really needed. It has the same line with Cameron (2001) statement who mention that the teachers take the crucial role to make preparation because there should be classroom activities that is appropriate for children's point of view who have their own limited way to build the understanding of what teacher says. In this case, the crucial role of teachers should be explored to face the challenges in teaching English for young learners which refers to T1's statement.

The challenges refers to the students unawareness and their unwillingness to study, even the students think that English is difficult. Considering this situations, teachers should have confidence to assume that it is not difficult things. Then the other challenges come from the student laziness that makes them strike to study.

The students' unawareness, unwillingness and laziness to study were the greatest challenges for the teacher. Literally, these challenges are in line with the theory of Pinter (2006) which mention that young learners' behavior which are usually more concerned about themselves than others. This is also confirmed by the teachers who stated that one of challenges comes from students' behavior. These conditions lead to anticipation done by the teachers. As T1 said in the interview.

That's right. I always start the learning process by encouraging and motivating students first. They will have some activities at the beginning time such as singing together and playing riddle. Then students who have want to answer or sing or just show their ability will come to forward and they still use English as usual.

Motivating and encouraging were important to keep their motivation in learning English. Giving praise and soft correction were effective not only maintaining the students' motivation but also keeping in track the material. The result of questionnaire below showed that the teacher put their attention on the students' respond.

Table 1.3

Questionnaire about teacher' response

\begin{tabular}{|l|l|c|c|}
\hline No & Item & Yes & No \\
\hline 4. & $\begin{array}{l}\text { In English teaching and learning, do you correct } \\
\text { students' wrong respond? }\end{array}$ & 3 & - \\
\hline
\end{tabular}

All of the teachers believe that by motivating, encouraging as well as responding their behavior wisely really help to keep the students' interest. These are regarded as ways to face the challenges in teaching English to young learners.

\section{Teacher as a Model}

The teacher acknowledges that the children's language acquisition is really good so that it becomes reason to have carefulness in giving material clearly. Since English is not student's first language, it is important for the teacher to serve as a model. In this case, the teacher gives model to the students in term of pronunciation. It was confirmed by the teachers through interview. 
When I make mistake in my pronunciation, however they will remember, even I correct it. For example, today I make mistake and tomorrow I correct it, "I am sorry my students, yesterday I was wrong to pronounce this word", and then they will answer "what is that, mom? You have said it before. So that's true" Sometimes there are students like that"

This occurrence indicates that teacher should be the source where the students can learn from. They should shows capabilities as English teacher. This includes materials, ways of thinking and arguing. It should be performed correctly. It has been said by Anggrarini (2016) who states that the teacher needs the basic knowledge to master the subject matter which includes the material, linking ideas, ways of thinking and arguing. In this study the researcher discovers that the teacher is really necessary to master the subject material which will be taught to students. Considering the mistake that happens in learning process, the researchers indicates that there will be anxiety among students that involves they are confuse to which one the right material or they lost the trust to their teachers because of the mistake itself and then when the teachers make a mistake, the first thing that the teachers do is admit the mistake and correct it. It is one of the requirements for teacher to build trust back among students as said by Anggrarini (2016) one of skills that teacher should be mastered is creating the conducive class as the effort to manage classroom situation.

\section{The Teachers' Ability to Make Emergency Activities for Unexpected Occurrence}

There will be high possibility of the unexpected occurrences in learning activity. One of the reasons behind this case is the nature of children which states by Pinter (2006) young learners as children have their own fantasy and imagination which construct the satisfaction of movement for them. These characteristic will give the effect to young learners' behavior which are usually more concerned about themselves than others. In this case, the students' behaviors are their expression to the learning activity which must give the impact whether it is good or bad based on teachers' perspective. It means that the teachers have to put high attention to students as the quick response to overcome the trouble that may be happen during the learning activity. This quick response is also applied by Mrs. Yustin to face the students by stating this statement.

So if the students show the bad response like bad mood or bored that is indicated through the way they answer our question and they only stuck at one activity, so it means that the students need refreshing by singing song or playing game.

Based on statement above, the monotonous of learning activities can influence the mood of students which has the impact to appear unexpected occurrences and in this study it refers to the unwillingness of students to continue their learning activities. In this study, there are some indications which come from students that show unexpected occurrences and it is added by the teacher.

However it is really necessary to do when they look bored. For example, the first and second grade must have their own activity such as running, fighting, and sometimes crying when they get bored.

The unexpected occurrences above will disturb the implementation of lesson plan because they do not belong to the content of lesson plan. It has been said by 
Anggrarini (2016) there will be possibility to unexpected occurrences frequently happen in learning activity. And one of unexpected occurrence is an internal disturbance, this unexpected occurrence can be found also inside the classroom and usually it comes from the students. Teacher must know first the reasons why the students make a noise or what they want for example, actually then teacher is easier to solve this. Considering this occurrence, teachers must have ability to overcome it. In this case Mrs. Yustin has creativity to create the preparation to overcome the unexpected occurrences by singing a song, playing puzzle, and playing riddle.

\section{CONCLUSION}

Lesson plan is one of requirements to conduct the successful learning activity. In this case, the teachers have high responsibility to consider the students' need in creating lesson plan. The consideration of students' daily life in creating lesson plan refers to the material choices which elaborate to the students' experience. Because when the materials were familiar for the students, it will be easier for them to learn and involve in learning process.

The use of textbook can be matched to the students' needs by doing some actions such as omit, add, adapt and replace. In this study, the teachers show the effort to adapt the textbook which proves that the lesson plan does not limit the teacher's creativity. Then the researcher determines the existence of textbook gives improvement for teachers to create lesson plan as long as they put the students as consideration.

The source of challenges of teaching English for young learners can appear from students' behavior. In this study, the researchers indicate the students' unawareness, unwillingness and laziness to study as the challenge of teaching English for young learner who is confronted by the teachers. In addition, the effort of English teachers to overcome these is also being the challenge one. The teacher has their own ways as the creativity to anticipate students' behaviors which can interrupt the learning objective and then the ways involve singing, playing games and playing riddle.

The teachers' competence is really necessary to ensure the reach of students' understanding to the material. Moreover the teachers must be careful in transferring the material and knowledge for students even it is a little point. The researchers find that the students can imitate the teacher thoroughly which is caused the children's language acquisition is really fast. So actually it becomes the weakness and strength in teaching English for young learner at the same time. It means that the teacher should be aware to what they say and what they teach because the students can absorb it straightforwardly without any consideration.

The characteristics of students which are more concerned to themselves are one of the reasons to the unexpected occurrences in learning activities. Usually, the unexpected occurrence does not belong to the teaching planning, but it will give the impact to the implementation of teaching. The resources of unexpected occurrences can be internal and external disturbance. However, the internal disturbance which comes from students is the most common phenomena. This phenomenon should be considered by the teacher in preparing the emergency activities which integrates 
to the lesson plan. In addition, the teachers conducted the several activities which involve singing and playing games which relates to the learning material as the emergency activities to overcome the unexpected occurrences so the students' focus can be mobilized back to the arranged learning activity.

\section{REFERENCES}

Anggrarini, Natalia. (2006). English for children; Compilation of Materials. Yogyakarta: Penerbit K-Media.

Brown, H. D. (2001). Teaching by Principles: An Interactive Approach to Language Pedagogy 2nd Edition. New York: Addison Wesley Longman, Inc.

Harmer, Jeremy. (2001) How to Teach English. Malaysia: VVP

Ismail, Çakir. (2004) Designing Activities for Young Learners in EFL Classrooms. GÜ, Gazi Eğitim Fakültesi Dergisi, Cilt 24, Sayı 3 101-112.

Nesari, Ali J.\& Mina, Heidari (2014) The Important Role of Lesson Plan on Educational Achievement of Iranian EFL Teachers' Attitude. International Journal of Foreign Language Teaching \& Research -Volume 3, Issue 5, Spring 2014.

Pinter, Anna M. (2006) Teaching Young Language Learner. Oxford University: Oxford Press.

Woodward, T. (2001). Planning Lessons and Courses: Designing Consequences of Work for the Language Classroom. Cambridge: Cambridge University Press. 